\title{
Tasarım Odağında Küreselleşmenin Kültürel ve Ticari Boyutları: Animeler ve Honda*
}

\section{Cultural and Commercial Dimensions of Globalization in the Focus of Design: Anime and Honda}

\section{Merve Yavuz \& Serkan Güneş \& Damla Şahin}

Endüstri Ürünleri Tasarım Bölümü, Gazi Üniversitesi, Ankara, Türkiye

\begin{abstract}
Özet
Küreselleşme, başlarda Anglosakson ekonomisinin, kültürünün ve tüketim unsurlarının diğer kültürler üzerinde baskınlık kurmasını ve toplumları aynılaştırmasını ifade etmiş olsa da, zamanla çevre ülkelerin ekonomik ve kültürel etkinlikleri nedeniyle tek-merkezcilikten çıkmıştır. Illetişimdeki gelişmeler ve düşen işlem maliyetleri neticesinde yerel kültürler de küreselleşme yoluna gitmiş, küreselin yereli kadar yerelin küreseli de kendilerini ifade edebilme imkanına kavuşmuştur. Küreselleşme ve kültür arasındaki ilişki ve temsil biçimleri günümüzde en yoğun tartışılan başlıklardandır. Kültürün iktisadi bir unsur olarak görülmesiyle birçok ülke, kültürünü küresel standartlarda sunma yarışına girmiştir. Kültür ve bileşenleri, uluslararası işletmenin pazar payı ve küresel rekabeti için önemli bir dayanaktır. Kültürün heterojen yapısına karşın gerekli koşullar sağlandığında, kültür ticari bir unsur olarak uluslararası pazara arz edilebilir ve heterojenlikten bağımsız her toplumda kabul görebilir. Küreselleşmeden kast edilen duvarları yıkılmış bir pazar kadar, kültür ile desteklenen ticari faaliyetlerdir. Günümüzde her toplum küreselleşmeden faydalanabilmek için kendi öz kültürünü ticari bir unsur olarak imkânları dâhilinde sunmaktadır. Bu çalışmada yukarıda sunulan hususlar üzerinden küreselleşmiş ve her toplumda takipçisi olan Japon manga ve anime kültürü ve onun ikincil ticari etkileri Japon Honda firması üzerinden tartışılacaktır. Çalışmada Honda firmasının manga ve anime kültürünü ürünlerine taşıması süreç analizi üzerinden ele alınacaktır.
\end{abstract}

Anahtar Kelimeler: Küreselleşme, Japon tasarımı, Honda, Anime.

\section{Abstract}

Although globalization expressed as a monocentrizm of the Anglosaxon economy, culture and consumption elements in the first place, over time, it has begun to be polycentrist because of the economic and cultural activities of the surrounding countries. As a result of the developments in communication and the decreasing transaction costs, local cultures have become globalized and the locals as well as the globals had the opportunity to express themselves. The relationship and representational systems between globalization and culture are the most intensely controversial topics today. Many countries have entered the race to present their culture at global standards, since the culture is regarded as an economic element. Culture and its components are an important basis for international market share and global competition. With the necessary conditions, cultural heterogeneit can be offered as a commercial element to an international market and accepted in any society independent of heterogeneous. What is meant by globalization is the commercial activities supported by culture, as well as a market without borders. Nowadays, every society pitches its own culture as a commercial element to capitalize globalization. In this study, Japanese manga and anime culture and its secondary commercial effects are discussed through Japanese firm Honda. In the study, Honda's handling of manga and anime culture to its products is discussed through process analysis.

Key Words: Globalization, Japanese design, Honda, Anime

CONTACT: Merve Yavuz, merveyavuz@gazi.edu.tr, ORCiD: orcid.org/0000-0003-0826-9023; Serkan Güneş, serkangunes@gazi.edu.tr, ORCID: orcid.org/0000-0003-4377-528X; Damla Şahin, damlasahin@gazi.edu.tr, ORCID: orcid.org/0000-0003-3756-5497

Geliş Tarihi \& First Received : 13.09.2017

Kabul Tarihi \& Accepted : :09.12.2017

* Bu çalışma, 27-29 Nisan 2017 tarihinde Antalya'da düzenlenen "Innovation and Global Issues in Social Sciences" adlı uluslararası konferansta sunulan "Cultural and Commercial Dimensions of Globalization in the Focus of Design: Anime and Honda" başlıklı bildirinin tam metine dönüştürülmüş halidir. 


\section{Introduction}

Giddens (2013:60) defines globalization as the concentration of social relations around the world, which associates distant local formations in such a way, that local occurrents are shaped by events occurring many miles away and vice versa. The OECD (1991) defines globalization as a phenomenon in which the dynamics of goods and services trade and the flows of capital and technology make markets and production in different countries increasingly interdependent. Global culture, one of the products that emerged with globalization, is expanding its living space by nourishing different cultures as time passes by (Nar, 2015).

Japan is not only a successful economic model and an industry group that produces and exports automobiles, electronics and other consumer goods, but also a cultural power that produces and exports cultural products and innovations (Otmazgin, 2003). An example of this is the globalization of the Japanese culture by the anime industry, which has spread all over the world, with the revenue of 1.812 trillion yen or 18 billion dollars in 2015.

In the first part of the study, the concept of globalization is explained briefly in the context of the study, and the reason why the Japanese industry is so effective in the whole world, both in terms of product and media items, is discussed in the light of Japanese design and cultural influences affecting it. Later, it is discussed the reunion of two different Japanese elements, which have developed after World War II and have seized the American market in global marketplace.

\section{Globalization}

Globalization refers to a complex phenomenon that embraces many economic, cultural, social, ideological concepts and these concepts interact with each other. Within the scope of the study, globalization is examined in terms of commercial and cultural dimension and their interaction.

The rise of global competition and the opening of new markets have reflected that all international companies have had to find new ways to think globally and act locally to develop products that meet local market needs while maintaining economies of scale (Ohtani et al, 1997: 4).

Globalization represents the triumph of a capitalist world economy connected by a global division of labour (Wallerstein, 1975). According to Featherstone, the globalization process simultaneously exposes two images of cultures. One means that a certain culture expands to its limits, that is, to the whole world. Heterogeneous cultures ultimately embrace the whole world by articulating and integrating dominant cultures. The second image expresses the compacting of cultures. The cultures formerly separated are brought into contact and fused. McLuhan (1960) suggested that advances in communication make the world a global village. UNESCO suggests that the world's becoming a global village blends cultures and communities closer together than ever before. But according to Castells (1996), people live not in a global village, but in a globally produced and locally distributed cabins. Nikitin and Elliot (2000), in a similar vein expressed globalization as the establishment of a global market devoid of sociopolitical control. In a sense, it can be said that the dynamics of convergence between cultures are commercial concerns and strategic approaches associated with them. 
Developing the right products for global markets means offering visible, tangible and distinctive product value to customers whether it is a global product to satisfy many markets, or different products for different markets (Ohtani et al, 1997:4).

Japanese producers have also achieved a strategic success in marketing their own cultural products. To infiltrate the European market, they first redesigned animations in their own manga style, and after Europeans adopted this style, they turned their cultural objects into a global phenomenon.

\section{Japanese Design}

According to Mente (2006: 14) Japanese design is a deeply rooted impulse to strive constantly increasing standards of design, quality and function based on traditional Japanese arts and crafts, and this effort which extends throughout the generations, has gradually infiltrated the nation's culture, eventually becoming an indispensable part of it. The standards of beauty and design are valid and similar for both the poor and the rich.

The rigid structure and the approach of avoiding all excess have prevented individuals from performing poor taste or departing very far from a graceful norm. However, the Japanese products developed over the centuries are not specially designed products to create value through the western approach, these products are common, ordinary goods already produced by traditional methods, unexperienced Japanese craftsmen (Mente, 2006:15). According to Mente (2006: 15) the beauty and purity of their work is conveyed to them by the traditions, values and talents of their ancestors and there is no distinction between life and art for them. There is no other culture where design and quality play such an important role in everyday life. The Japanese has not only institutionalized good design and quality but also ritualized it. They can even be said to have transformed a good design and quality into a religion. Every object from daily living to artworks, which is revealed in this society where each individual has high pleasures, has become a universal standard. Despite the modernization and westernization, Japanese art, craft and design has not only survived, but with Japanese design, Japanese culture has also affected the whole world and become global.

According to Sparke and Antonelli (2009:12), especially in the last half century Japan has nurtured a distinctive modern design culture. By embracing contemporary visual and material cultures, Japanese designers have evolved a new aesthetic and value system while holding firmly to tradition. This system exerted strong international influence by affecting architecture, interior design, product design, fashion design, graphic design and craft around the world. Japanese designers have been leaders of both the modern and postmodern design with their endless curiosity, the intention of building a new world through art and design (Spark and Antonelli, 2009:10)

\section{Anime as a Japanese Soft Power Weapon}

Anime is a Japanese abbreviation of the English word "animation" (Napier, 2001). In English, the term anime means Japanese animated cartoon and is used both singular or plural. According to Napier (2001), Japan has become an increasingly significant player 
in the global cultural economy through anime. According to Newitz (1994), anime is the chief cultural export of Japan.

Unlike Western comics and animations, manga and anime are developed from historical art in Japanese culture (Brenner, 1997). And anime are factual because they are adult oriented unlike Western animation is aimed largely at children (Newitz, 1994) According to Napier, anime are useful mirrors that reflect contemporary Japanese society, based on traditional Japanese culture, offering a different view of today's universal issues, dreams and nightmares, with a rich and wide range of subject matter.

While the earliest known Japanese animation dates to 1917, and many original Japanese cartoons were produced in the ensuing decades, the characteristic anime style developed in the 1960s notably with the work of Osamu Tezuka and became known outside Japan in the 1980s (By Wikipedians, 2010a: 95). While anime had entered markets beyond Japan in the 1960s, it grew as a major cultural export during its market expansion during the 1980s and 1990s. The anime market for the United States alone is "worth approximately $\$ 4.35$ billion, according to the Japan External Trade Organization (By Wikipedians, 2010a: 261). Anime have also had commercial success in Asia, Europe and Latin America, where anime have become even more mainstream than in the United States (By Wikipedians, 2010a: 261)

The anime first entered the American market before 1975, with many adaptations. In the 1930s, due to the commercial success and international popularity of American animation, most anime was drawn in Disney and Warner Brother's cartoons' style (Patten, 2004). This trend lasted until the end of World War II, when the anime style characters of Osamu Tezuka (Astro Boy and Kimba The White Lion) which are created with unique characteristics went beyond visual objects borrowed from Disney (Lewis, 2000). He simplified Disney's animation techniques to reduce costs (By Wikipedians, 2010b: 256). $\mathrm{He}$ intended this as a temporary measure to allow him to produce material on a tight schedule with inexperienced animation-staff (By Wikipedians, 2010b: 256). Over time, his work and that of other pioneers in the field inspired characteristics and genres that remain fundamental elements of anime today, and the anime has formulated its own distinctive style (the always-present black lines, the deaths of main characters, serious and adult themes, large eyes) including moving the mouths as facial expressions remain unchanged ( $\mathrm{Lu}, 2008)$. As it developed, anime returned the animation world the favor with fundamental change that exceeds the original crude mimicry (Lu, 2008).

Anime differ not only visually but also contextual from the western animations (Brenner, 1997: 83). For example, in the science fiction anime Astro Boy, Tezuka has questioned contradictions between man and machine, dealing with the potential hazards of technology development, the moral collapse of society and the destruction of resources (Brenner, 1997: 7). In Kimba The White Lion, it has been observed that a young lion grows up to become an adult instead of a non-natural continuous existence in Westerns' (Brenner, 1997:7). Anime are designed for not only children and young people but also for adults and crime, violence and sexual content have not been avoided. Black-and-white view of the world has been abandoned and bad heroes have been embraced (Brenner, 1997: 32). 
Figure 1. "Kimba The White Lion" Anime character created by Osamu Tezuka

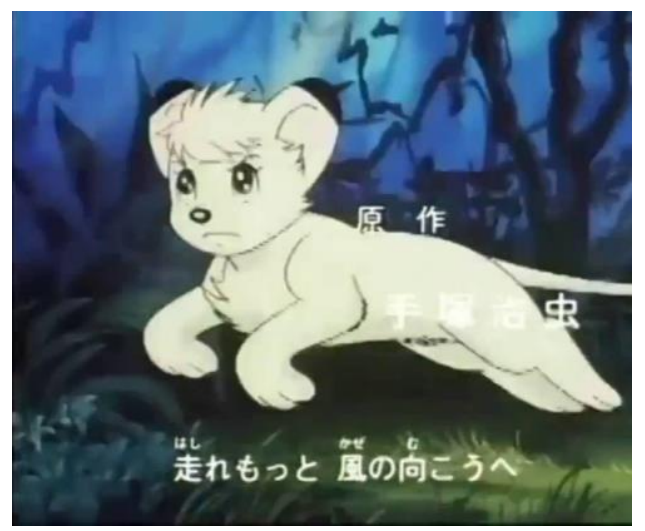

Source: https://i.ytimg.com/vi/L2cScp6qpT8/maxresdefault.jpg 10.04.2017

Figure 2. "Astro Boy” Anime character created by Osamu Tezuka

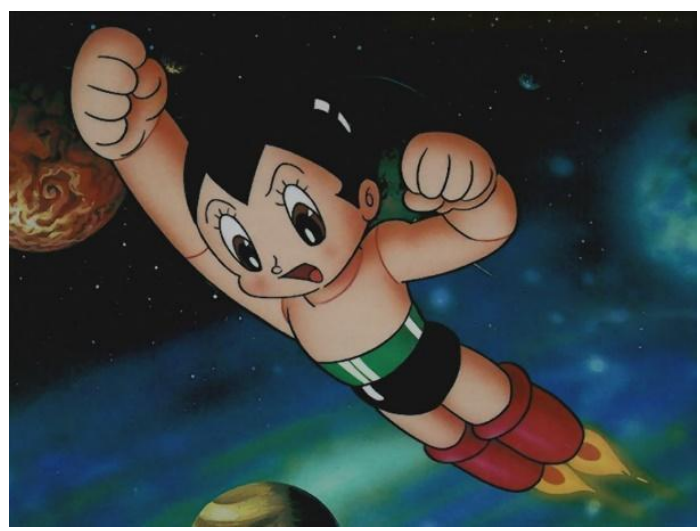

Source:http://static.tvtropes.org/pmwiki/pub/images/lt/astroboy.gif 10.04.2017

Since 1980s, Japan has become a cultural superpower due to the international success of anime and manga works such as "Dragonball" and "Nausicaa of the Walley of the Wind" (Sabbagh, 2015). In 1992 and 1993, 58\% of the world's animation film exports were made by Japan (Iwabuchi, 1995). In 2003, anime and related products constitute about one third of the income of the world media market (Nakamura, 2003). Worldwide exports of Japanese products have not only fascinated western audiences with the differentiated features of animations such as "Akira" but also have aroused their interest in everything Japanese like history, pop culture, etc (Sabbagh, 2015).

In the early 2000s, the Japanese government began to evaluate the popular culture industry of the country after the international successes of anime-manga (Pokemon, Dragonball), games (Nintendo's Legend of Zelda and Super Mario series) and movies (Spirited Away, Ringu). Thus, the Japanese government used creative industries, including mecha, one of the oldest and most influential anime genres, to increase cultural exports, in order to increase their soft power (Sabbagh, 2015). The origins of the Japanese mechas have their origins in the Second World War that Japan has witnessed the 
destructive power of modern technology that lifts Hiroshima and Nagasaki. These dramatic events later became the inspiration for surviving Japanese cartoonists (Sabbagh, 2015). One of these anime types is the "Astro Boy" mentioned earlier. It is a story of an android that fights crime with mechanical powers yet is capable of displaying human emotions, essentially acting as an interface between man and machine (Sabbagh, 2015). In Japan's invasion and post-occupation years (1945- early 60's), the explosion of artistic creativity took place in the manga industry (Sabbagh, 2015). Despite the economic declines of the decade after the Second World War, Japan has begun to develop the idea of 'Cool Japan', which expresses the emerging status as a cultural superpower to increase cultural exports from its creative industries, including one of its oldest and most influential anime genres: mecha (Sabbagh, 2015). Thus, the anime industry has become a soft power weapon, not merely a commercial product.

The soft power is used from a country to persuade the world the correctness of its ideas and principles and make them accepted these through cultural attraction and ideology instead of military power (Nye, 1990). In today's international politics, soft power is used to support and conceal the application of both military and economic power (Otmazgin, 2003). According to Otmazgin (2003), in a similar vein, the goal of this use in a country with global influence is to persuade the world and convince them of its own principles and ideas. In this context, culture is seen as a tool for public relations and a way of strengthening the influence of a country, and cultural industries play an important role in this process (Otmazgin, 2003). In Western admittance, Japan has a soft but invasive cultural power achieved with a positive image instead enforcing (Nye, 2004).

According to Lam (2007), Japan tries to project its soft power in manga and anime attractiveness in public diplomacy, but manga and anime production, dissemination and global consumption are driven not by the government but by the market forces and consumer tastes.

In addition to its cultural power, Japan is at the forefront of the global market with its industry, and the Honda Corporation is one of the important components of that.

\section{Global Local Corporation Honda}

Today, in addition to manga and animations, Japan is well known for its electronics and automotive industries. The Japanese industries have made remarkable progress since World War II, and some have achieved competitive positions in the global market (Porter, 2011). The Japanese motorcycle industry is one of them. In the post-war period, the industry has experienced many new initiatives, rapid technological change, a marked growth in market demand and a sudden drop in prices (Kato, 2008). As a result, the Japanese motorcycle industry turned into an oligopoly, while Japanese companies Honda, Kawasaki, Yamaha and Suzuki became leaders in the global motorcycle market in the early 1960s (Kato, 2008). In terms of export share, the motorcycle industry has become Japan's most successful industry (Porter, 2011). Honda became the global market leader when the Super Cub was introduced to the market in 1958 (Otahara, 2000) and followed by other Japanese motorcycle manufacturers such as Yamaha, Kawasaki and Suzuki (Fujita, 2007).

The Boston Consulting Group published a report in 1975 entitled "Strategy Alternatives for the UK Motorcycle Industry," which also covered Honda's market success. According to the report, the source of the success of Japanese producers was the 
growth in the local market in the 1950s. At the time when only 4 percent of motorcycles were exported, the production of small motorcycles in the local market caused a decrease in product costs, and in such an environment where competition is intense, Honda has entered the American market with a strong position in the 1960s with low-cost, lowpriced small motorcycles (Boston Consulting Group, 1975).

Figure 3. Honda Model Super Cub

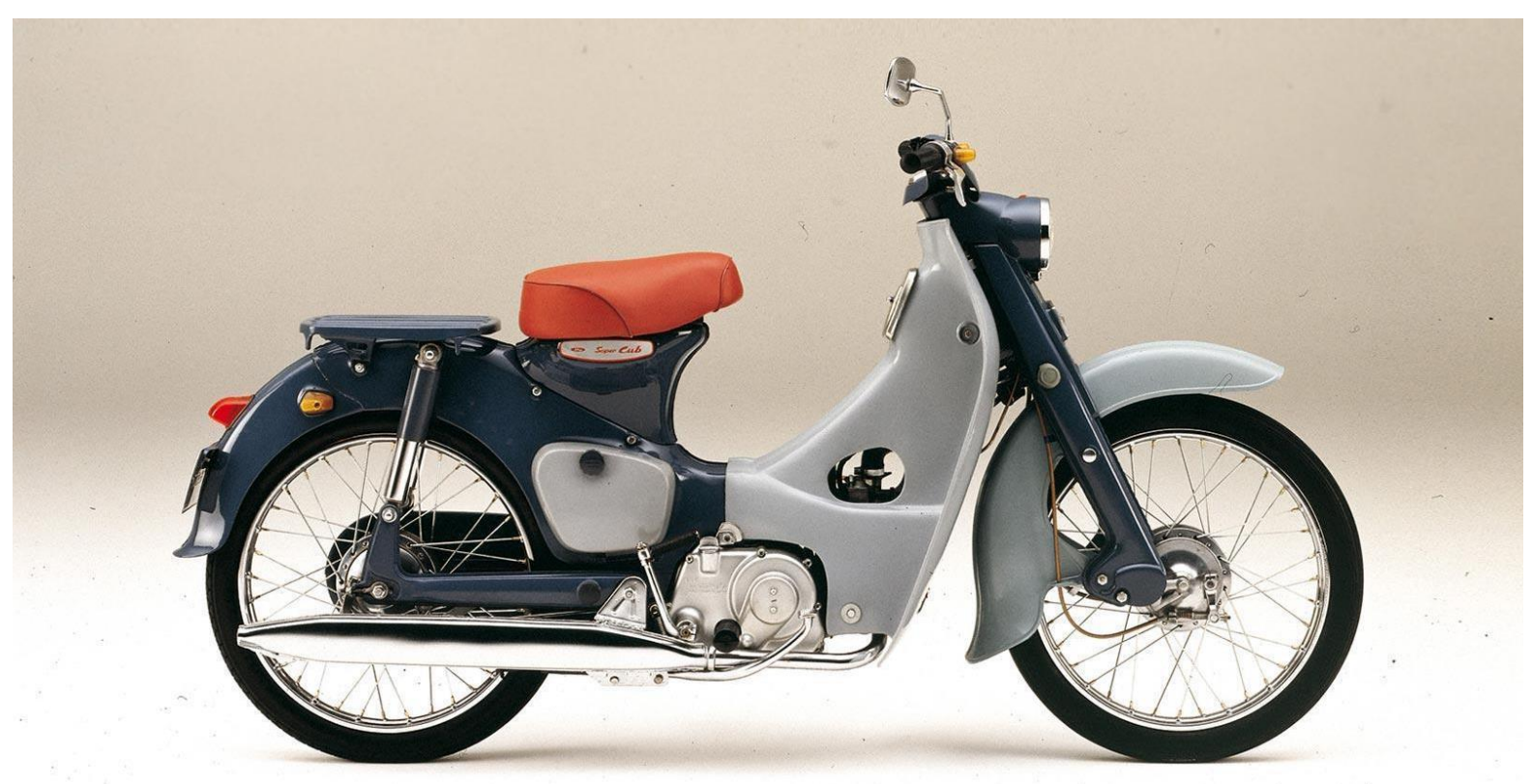

Source: http://www.asphaltandrubber.com/wp-content/uploads/2014/05/HondaSuper-Cub-C100.jpg 06.04.2017

According to the report, the only reason of Honda's success is not low costs, but rather by assigning new meaning to motorcycles, Honda creates new markets in the US and other countries with advertising and promotion efforts. Honda has made motorcycling an entertainment tool, making more attractive than any motorcycle producer has ever done before. Someway, the success of the campaign, which depends on the light weights of the vehicles as a last resort, evolves out of the fact that motorcycles are fun, easy-touse and do not have mechanical problems frequently unlike their counterparts.

In the report, motorcycle industry has been approached with social and commercial aspects, and the behavior of Honda in this industry has been examined chronologically. Companies in the US motorcycle market have undergone a major transformation in the 1960s. Motorcycle records increased from 575,000 in 1960 to 1,382,000 in 1965. Before 1960, the US market was mostly shared by United States Harley-Davidson, UK BSA, Triumph and Norton and Italian Moto-Guzzi. Harley was the market leader in 1959 with total sales of \$ 16.6 million. After the Second World War, motorcycles in the United States were demanded by a very limited group of people, except for police and army 
personnel using motorcycles for work. Most motorcyclists were undoubtedly good people, but those who call themselves "Hell Angels", "Satan's Slaves" have created a bad image of motorcycling. Even leather jackets worn by motorcyclists as protective devices have gained an ugly image. The film titled "The Wild Ones," starring Marlon Brando with a black leather jacket and a 650cc Triumph motorcycle, enabled bully motorcyclists to have wide media coverage. The motorcyclist perception in the society was leathercovered, bulging adolescents.

Unlike other foreign producers, in 1959, Honda set up a subsidiary in the United States called American Honda to avoid being dependent on distributors. In its 1963 annual report, Honda's marketing strategy was described as a policy of selling to the ones who had never considered themselves on motorcycle before rather than confirmed motorcyclists. Honda penetrates into the US market with the smallest, lightest and easiest to ride motorcycles. These motorcycles were equipped with three-speed transmission, automatic clutch, five horsepower, electric starter and step-through frame for female drivers. Honda motorcycles were sold under \$250 in retail prices, while American and British motorcycles were sold at a price range of $\$ 1,000$ to $\$ 1,500$. Even in the early days, Honda was superior to other competitors in terms of efficiency.

Despite the total of 100 artisans and engineers employed by American and European competitors until June 1960, a total of 700 designers and engineers took part in Honda's $\mathrm{R} \& \mathrm{D}$ effort. Honda's fixed asset investment per employee was twice that of its competitors. Honda became the world's largest motorcycle manufacturer with \$55 million in sales in 1959. Honda sold 2,500 machines in the US in 1960 and in 1961, spent $\$ 150,000$ on advertising. The advertising was directed at young families, and the theme was "Meet the Nicest People on Honda". This was a deliberate attempt to purge the motorcyclists from groups like the "Hell Angels".

Honda's success in creating demand for lightweight motorcycles was phenomenal. American Honda's sales rose from \$ 500,000 in 1960 to $\$ 77$ million in 1965. Until 1966, market share data showed the superiority of Japanese manufacturers and the success of selling light motorcycles. According to Pascale (1984), Honda's success lie in the leadership features in product design of company founders Soichiro Honda and Takeo Fujisawa and the process of evolving an innovative design from a high-tech small motor. According to Mair (1999), it is primarily the advanced technology and innovative design of Super Cub, which enabled Honda to become the world's largest motorcycle manufacturer in 1959.

In addition to the Boston Consultant Group, Pascale (1996) has attributed Honda's achievement to its organizational culture and the Honda strategy being shaped by the Japanese approach that is not rigidly planned by senior management, but acts as a process that evolves from bottom to top with communication. In a sense, it can be said that it is its locality, which makes Honda global.

\section{Reunite of Two Local Elements in Global Market}

The Japanese company Honda, which entered the US market with lightweight motorcycles in the 1960s, appears to be renewing its strategy with its new designs today. In the final part of the work, the reuniting of cultural and industrial two elements belong to Japan, which dominates the American market in different industries, are examined. 
In the first example, a Honda motorcycle that is transformed into anime style and its turning into a media item is shown. Yutaka Izubuchi, director of several major animations such as "Space Battleship Yamato", "The Mask Rider" and "Evangelion", says on the visit to the Honda Corporation in 2015, that the design conscious small motorcycles are becoming the trend in the global market. In Izubuchi's Masked Rider manga that he delicately worked on as an anime designer, Masked Riders's Cyclone motorcycle was Honda, 2004 model CBR1000RR. Izubuchi has stated that they are surprised, have difficulty in transforming motorcycle into anime, and surprised by that motorcycles can be so futuristic and have so much character.

Figure 4. Honda 2004 Model CBR1000

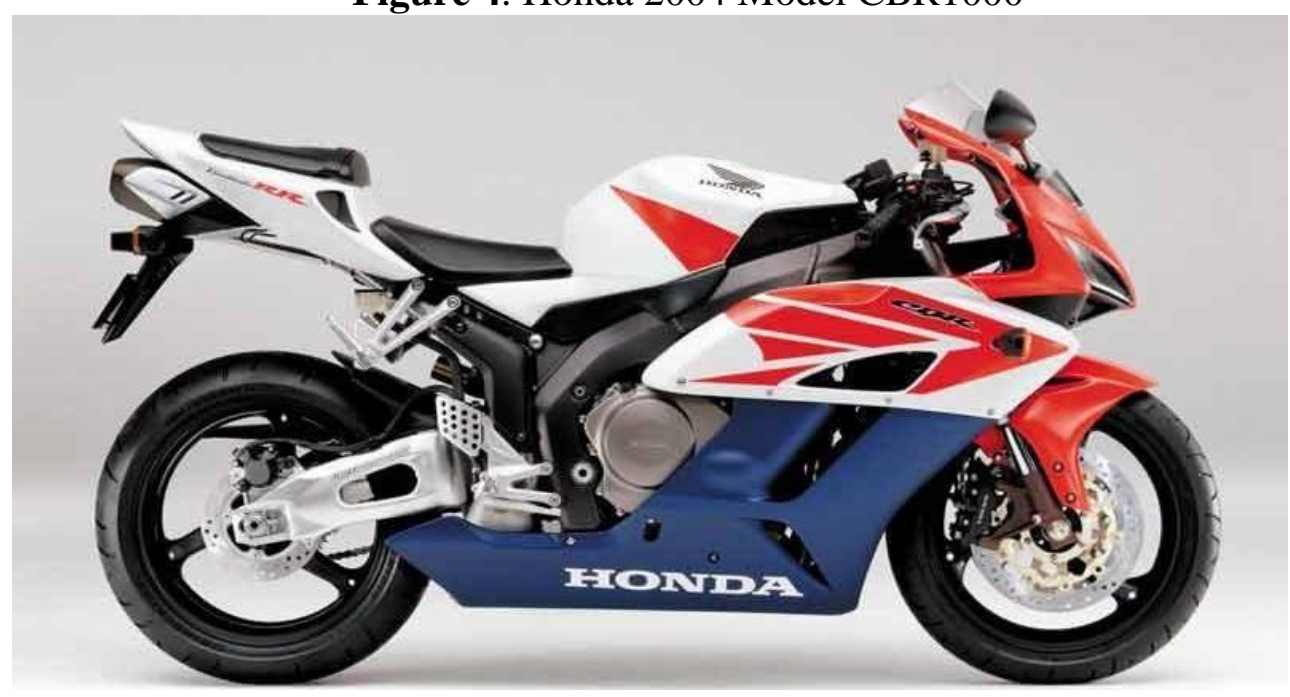

Source: http://images.mcn.bauercdn.com/upload/818/images/147065@hondacbr1000rr-fire.jpg 10.04.2017

Figure 5. Masked Rider's Cyclone motorcycle

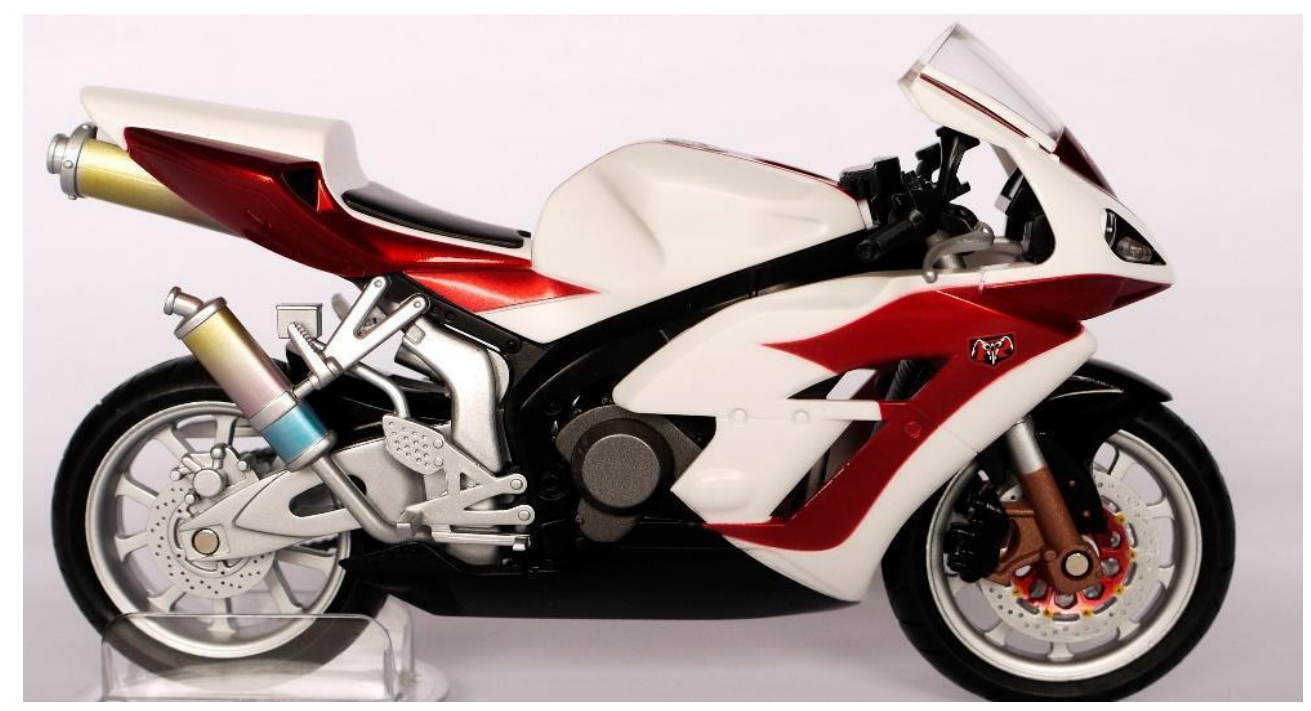

Source: https://akashingou.wordpress.com/2011/09/13/review-s-h-figuarts-excyclone-first-ver/ 10.04.2017 
The second example is the motorcycle NM4-02 which Honda designed in "mecha" style of manga and animations. Mecha is an abbreviated version of the English Mechanism in Japanese (Sabbagh, 2015), and the term refers to scientific thought and science fiction forms based on robots or machines controlled by humans. Honda's NM402 model motorcycle is called the Tsugomori version. Tsugomori is the mecha of the chief character in the "Knights of Sidonia" anime.

Figure 6. "Knights of Sidonia" manga cover

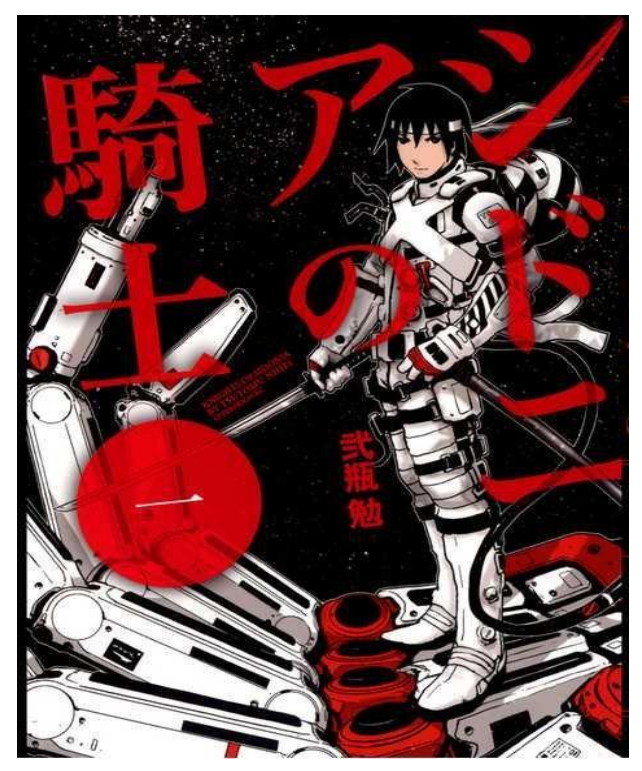

Source:https://en.wikipedia.org/wiki/Knights_of_Sidonia\#/media/File:KOS_1_Cov er.jpg 12.04.2017

Figure 7. Honda NM4-02 motorcycle

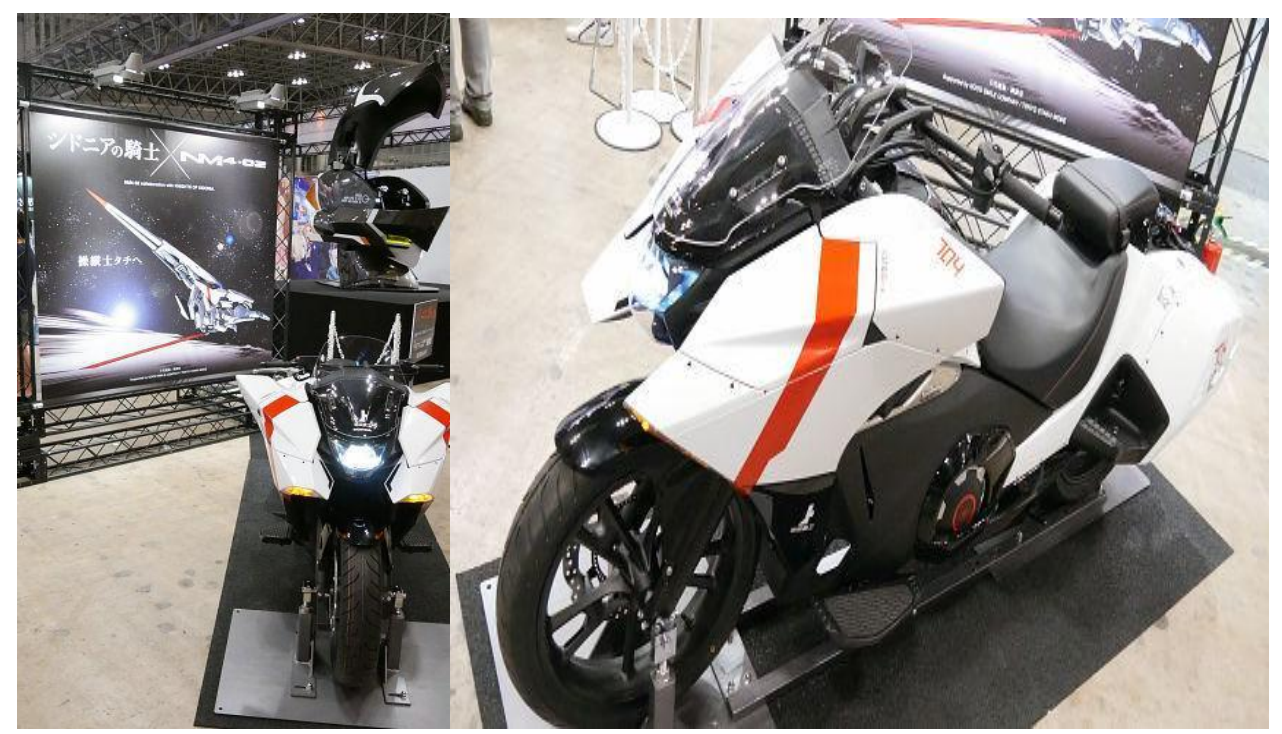

Source:http://www.animenewsnetwork.com/interest/2014-08-12/honda-shows-offa-knights-of-sidonia-style-motorcycle/.77011 12.04.2017 
Third, the Honda Corporation's new market-creating strategy and inspiration from anime in motorcycle design have been exemplified on the NM4 motorcycle.

Figure 8. Honda NM4 Vultus

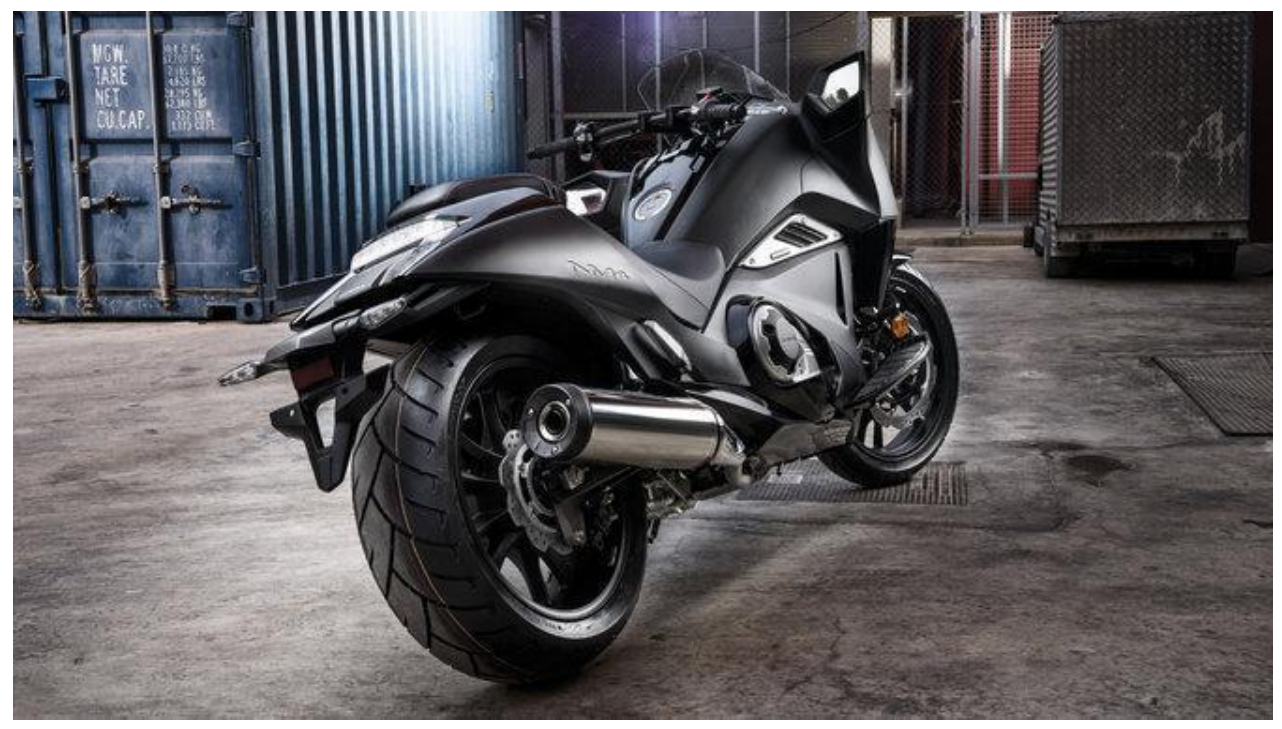

Source: http://www.honda.co.uk/motorcycles/range/custom/nm4-vultus2014/overview.html 10.04.2017

Figure 9. Kaneda's motorcycle in Akira anime

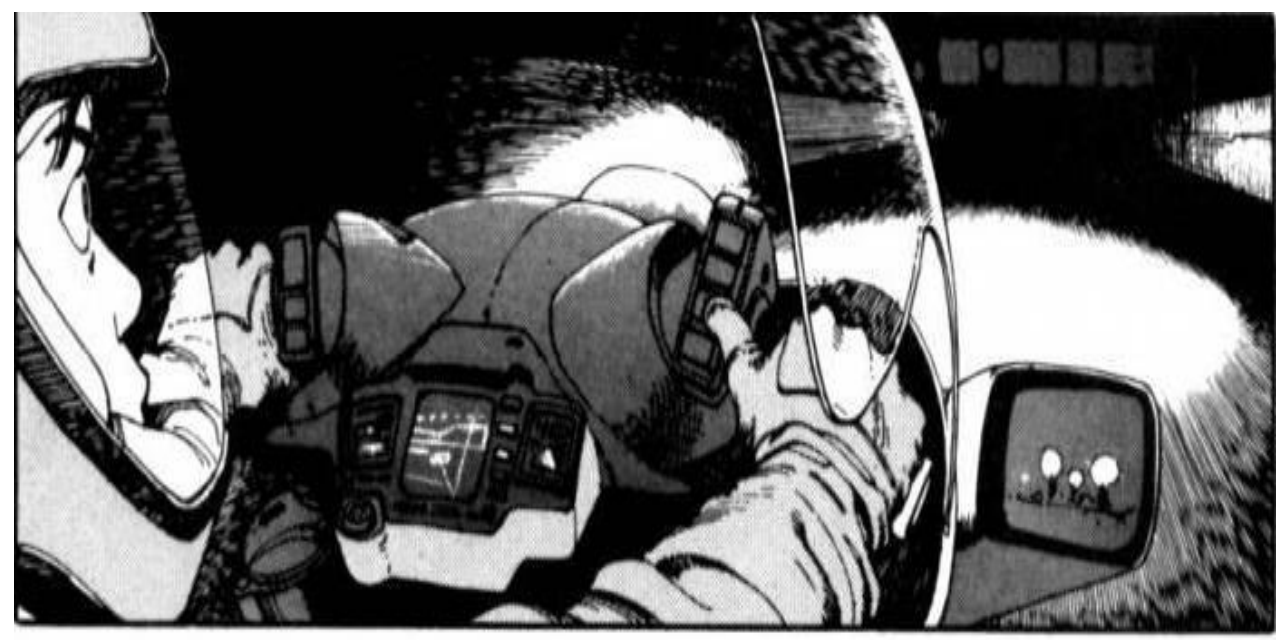




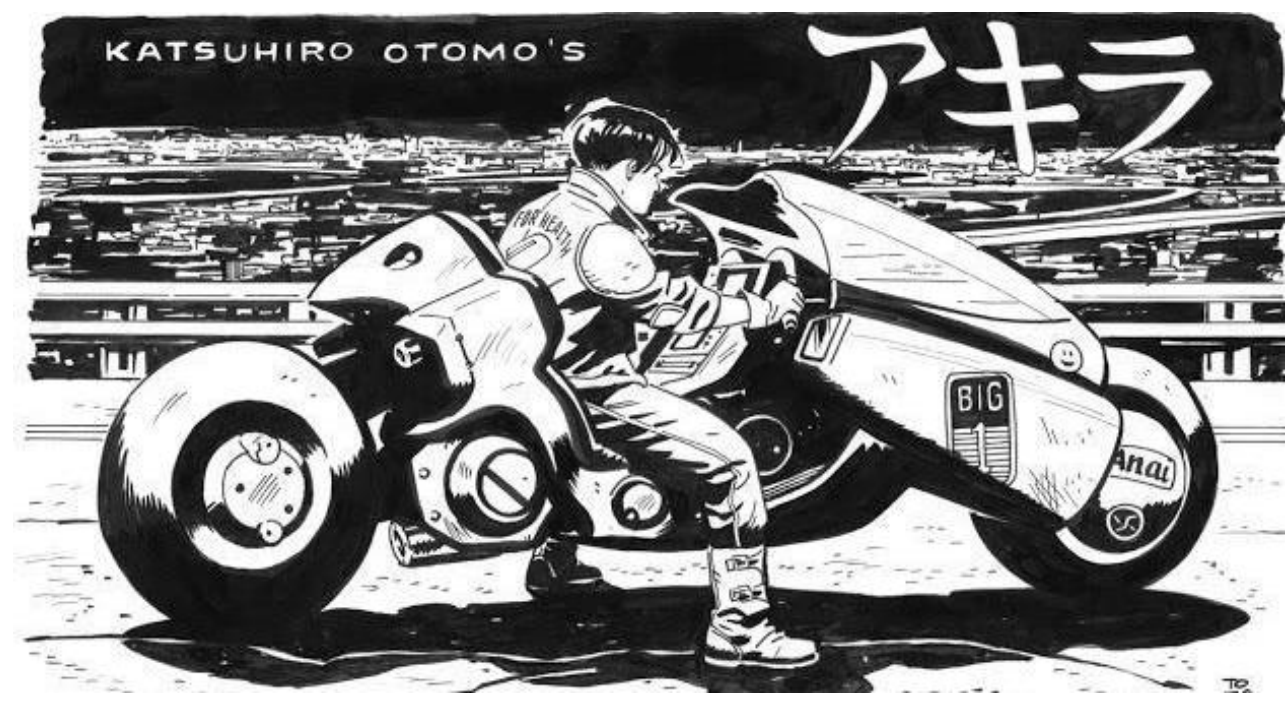

Source: http://www3.mangafreak.net/Read1_Akira_1_16 10.04.2017

After the presentation of the NM4 Vultus at the Osaka Motorcycle Show in 2014, the idea that it is inspired by the futuristic motorcycles in anime in the design process emerged in the dominant and powerful lines are often identified with the motorcycle of the Kaneda character in Akira anime. Honda (2014) says that the NM4 series are designed to gain character and depth, and these motorcycles with auto-transmission will create a huge new market. Honda states that they designed a motorcycle that will arouse interest in those who do not use a motorcycle with a different look and performance with a strategy like that of a Super Cub motorcycle. In 2017, Honda achieved global success. It has supported DreamWorks Pictures and Paramount Pictures, which adapt the manga "Ghost in the Shell" to a film, and the NM4 motorcycle model has become a media item as the film's heroic motorcycle.

Figure 10. "Honda NM4 and "Ghost in the Shell" cover

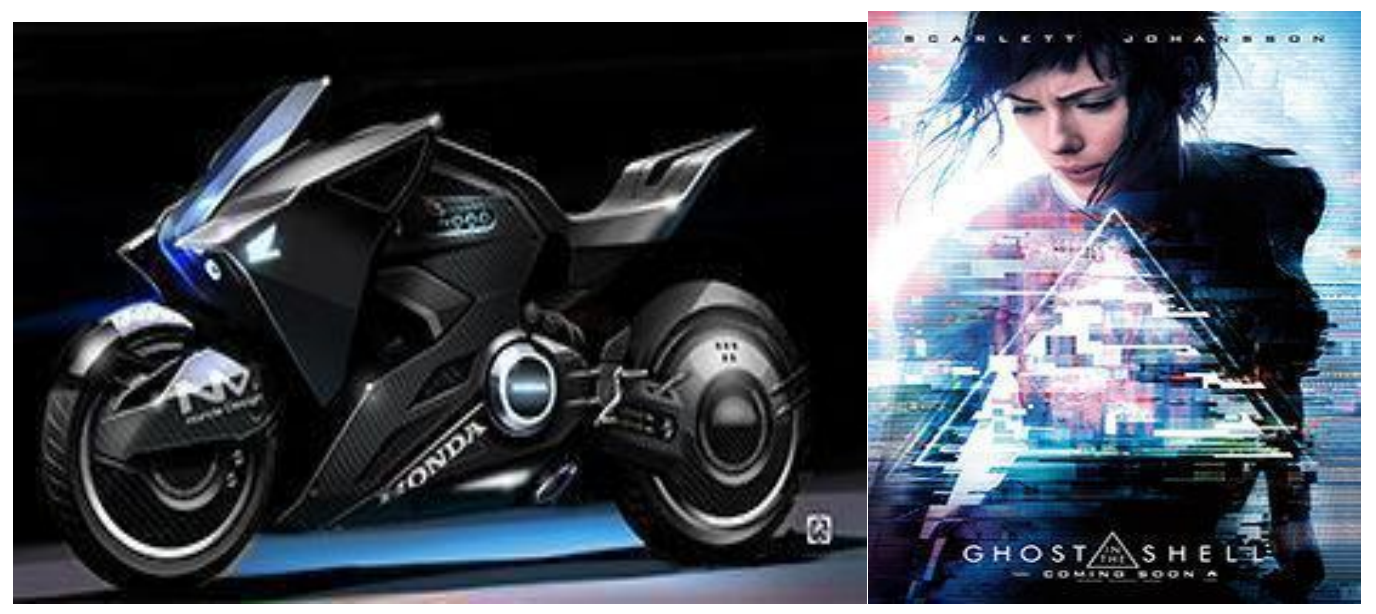

Source: http://world.honda.com/news/2017/2170317eng.html 10.04.2017

Use of a media item of a motorcycle designed by a Japanese firm inspired by Japanese anime in American movie that adopted from Japanese manga is a striking example of the relationship between culture and economy in globalization. 


\section{Conclusion}

The anime industry has not only been used as a policy tool by the Japanese government with its global impact, but also a global brand such as Japan's Honda has benefited from anime in its designs to enhance its commercial success. In the study, examples of Honda's use of anime-mecha style in motorcycle designs are shown. The globalization of an artistic product and its transformation into a commercial product, and even how it affects other global industries in the context of design are put forward through Japanese animations and the Honda Corporation.

\section{References}

Brenner, R. E. (2007). Understanding Manga and Anime. Greenwood Publishing Group, 356.

By Wikipedians, 2011. Anime and Manga, Pedia Press, 563.

By Wikipedians, 2011. Japan, Pedia Press, 880.

Broadbent, M. (1998). The phenomenon of knowledge management: what does it mean to the information profession?. Information Outlook, 2(5), 23-37.

Castells, M. (2005). A ̆ Toplumunun Yükselişi. İstanbul Bilgi Üniversitesi Yayınları, 714.

De Mente, B. L. (2011). Elements of Japanese design. Tuttle Publishing, Kindle Edition, 162.

Dresser, J., Goold, M., \& Hendley, B. (1975). Strategy Alternatives for the British Motorcycle Industry, A Report Prepared for the Secretary of State for Industry by the Boston Consulting Group Limited.

Fujita, M. (2007). Local Firms in Latecomer Developing Countries amidst China's Rise The case of Vietnam's motorcycle industry, Institute of Developing Economies.

Giddens, A. (2013). The consequences of modernity. John Wiley \& Sons. 200.

Internet: Honda futuristic motorcycle based on the NM4 makes appearances in the feature film "Ghost in the Shell". http://world.honda.com/news/2017/2170317eng.html $\underline{11.04 .2017}$

Internet: http://akihabaranews.com/2014/03/26/article-en/honda\%E2\%80\%99s-newnm4-concept-bike-straight-out-cyberpunk-anime-184098454

Internet: Roberson, B. (2014). Guess again: Honda's NM4 Vultus isn't a scooter, electric, or Batman's new ride. http://www.digitaltrends.com/cars/hondas-radical-newvultus-sounds-like-electric-bike-isnt-batman-probably loves/ 11.04.2017

Internet: George, A. (2014). Honda Goes Full-Blown Anime With Its Latest Bonkers Bike. https://www.wired.com/2014/03/honda-anime-motorcycle/ 11.04.2017

Internet: George, P. (2014). Honda's Anime-Inspired Bike Is A Stealth Bomber On Two Wheels. $\quad$ http://jalopnik.com/hondas-anime-inspired-bike-is-a-stealth-bomber-ontwo-1548856559 11.04 .2017

Internet:http://www.animenewsnetwork.com/interest/2014-08-12/honda-shows-off-aknights-of-sidonia-style-motorcycle/.77011 
Internet: Kieldsen, S. (2014). Meet Honda's anime-inspired NM4 Vultus motorcycle. https://www.stuff.tv/news/meet-hondas-anime-inspired-nm4-vultus-motorcycle $\underline{11.04 .2017}$

Internet: Mcdonald, S. (2014). Honda Nm4: Spending Time With Honda's Anıme Blke https://www.revzilla.com/common-tread/honda-nm4-spending-time-with-hondasanime-bike 11.04.2017

Kato, M. (2008). Firm Survival and the Evolution of Market Structure: The Case of the Japanese Motorcycle Industry. Hitotsubashi University, Tokyo, JP.

Lam, P. E. (2007). Japan's quest for "soft power": attraction and limitation. East Asia, 24(4).

Lu, A. S. (2008). The many faces of internationalization in Japanese anime. Animation, 3(2), 169-187.

Mair, A. (1999). Learning from Japan?: interpretations of Honda Motors by strategic management theorists (Vol. 29). Nissan Institute of Japanese Studies..

Napier, S. J. (2016). Anime from Akira to Howl's moving castle: Experiencing contemporary Japanese animation. St. Martin's Griffin, 2nd Edition, 384.

Nar, M. Ş. (2015). Küreselleşmenin tüketim kültürü üzerindeki etkisi: teknoloji tüketimi. The Journal of International Social Research, 8(37), 941-954.

Newitz, A. (1994). Anime otaku: Japanese animation fans outside Japan. Bad Subjects, 13(11), 1-14.

Nye, J. S. (1990). Soft power. Foreign policy, (80), 153-171.

Ohtani, N., Duke, S., \& Ohtani, S. (1997). Japanese Design and Development. Gower Publishing Company.

Otahara, J. (2001). An Evolutionary Phase of Honda Motor. Japanese Yearbook on Business History, 17, 109-135.

Otmazgin, N. K. (2008). Contesting soft power: Japanese popular culture in East and Southeast Asia. International Relations of the Asia-Pacific, 8(1), 73-101.

Pascale, R. T. (1984). Perspectives on strategy: The real story behind Honda's success. California Management Review, 26(3), 47-72.

Pascale, R. T. (1996). The Honda Effect. California Management Review, 38(4), 80.

Patten, F. (2004). Watching anime, reading manga: 25 years of essays and reviews. Stone Bridge Press.

Porter, M. E. (2011). Competitive advantage of nations: creating and sustaining superior performance. Simon and Schuster.

Sabbagh, M. (2015). Effort Upon Effort: Japanese Influences in Western First- Person Shooters (Doctoral dissertation, Worcester Polytechnic Institute).

Sparke, P., Antonelli, P. (2009). Japanese design. The Museum of Modern Art. 160. 